\title{
Intra-articular therapy with methotrexate or tumor necrosis factor inhibitors in rheumatoid arthritis: a systematic review
}

\author{
Megan M. Sullivan ${ }^{1 *}$ D, Michael M. Pham², Lisa A. Marks ${ }^{3}$ and Fawad Aslam²
}

\begin{abstract}
Background: Persistent monoarthritis in otherwise well-controlled rheumatoid arthritis presents a therapeutic challenge. Intra-articular (IA) steroids are a mainstay of treatment, though some have queried whether IA disease modifying anti-rheumatic drugs (DMARD) and biologics can be used in those who fail steroid injections.

Methods: A systematic literature review was conducted using four medical databases to identify randomized, controlled trials assessing IA therapies in RA patients. Included studies underwent Cochrane Risk of Bias 2 assessment for quality.

Results: Twelve studies were included, 6 of which examined intra-articular (IA) TNF inhibitors (TNFi), and 6 studies evaluating IA methotrexate. Of those evaluating IA TNFi, one study reported statistical improvement in TNFi therapy when compared with placebo. The remaining 5 studies compared IA TNFi therapy with steroid injections. IA TNFi had statistically improved symptom scores and clinical assessments comparable with IA steroid treatments. In the 6 studies evaluating IA methotrexate, the addition of methotrexate to steroid intra-articular therapy was not found to be beneficial, and singular methotrexate injection was not superior to the control arms (saline or triamcinolone). Risk-of-bias (ROB) assessment with the Revised Cochrane ROB tool indicated that 2 of 6 TNFi studies were at some risk or high risk for bias, compared with 5 out of 6 methotrexate studies.

Conclusion: For persistent monoarthritis in rheumatoid arthritis, IA methotrexate was not found to have clinical utility. Intra-articular TNFi therapy appears to have equal efficacy to IA steroids, though the optimal dose and frequency of injections is yet unknown.
\end{abstract}

Keywords: Rheumatoid arthritis, Intraarticular, Monoarthritis, Joint, Injection, Corticosteroid, Methotrexate, Review, Tumor necrosis factor inhibitor

\section{Background}

The continued expansion of immunosuppressive medication options has greatly improved disease activity control in rheumatoid arthritis (RA) patients. However, persistent symptomatic monoarthritis can be a problem in some patients who otherwise have satisfactory disease

\footnotetext{
* Correspondence: meyer.sullivan2@mayo.edu

'Division of Rheumatology, Department of Internal Medicine Mayo Clinic, 4500 San Pablo Road, Jacksonville, FL 32224, USA

Full list of author information is available at the end of the article
}

control [1]. Intra-articular (IA) steroid injections have remained a treatment cornerstone for these patients, but the need for other therapies is clear. Patients can fail such therapy, may develop adverse effects or have comorbidities that are exacerbated by intra-articular steroids. Almost $50 \%$ of patients can relapse after an IA corticosteroid injection [2]. There can be patient and provider hesitation, primarily driven by concern for adverse effects, to add or escalate systemic immunosuppressive treatment for isolated monoarthritis. A similar

(c) The Author(s). 2021 Open Access This article is licensed under a Creative Commons Attribution 4.0 International License, which permits use, sharing, adaptation, distribution and reproduction in any medium or format, as long as you give appropriate credit to the original author(s) and the source, provide a link to the Creative Commons licence, and indicate if changes were made. The images or other third party material in this article are included in the article's Creative Commons licence, unless indicated otherwise in a credit line to the material. If material is not included in the article's Creative Commons licence and your intended use is not permitted by statutory regulation or exceeds the permitted use, you will need to obtain permission directly from the copyright holder. To view a copy of this licence, visit http://creativecommons.org/licenses/by/4.0/. The Creative Commons Public Domain Dedication waiver (http://creativecommons.org/publicdomain/zero/1.0/) applies to the data made available in this article, unless otherwise stated in a credit line to the data. 
situation arises in some patients with isolated inflammatory monoarthritis, without an associated systemic disease or even an underlying diagnosis, where systematic immunosuppressive treatment may seem aggressive compared to the more localized IA therapy.

The aforementioned clinical scenarios are uncommon but real problems seen in everyday rheumatology clinical practice. After exhausting IA steroid treatments, therapeutic paths forward are unclear. In such situations, surgical and radiation-induced synovectomy have been employed as treatment approaches [3, 4]. Several studies have looked at the utility of other IA immunosuppressive treatments as a management option for persistent inflammatory monoarthritis. The medicines studied have included methotrexate and tumor-necrosis-factor inhibitors (TNF-i). The aim of this systematic review was to evaluate the suitability and effectiveness of IA methotrexate and/or IA TNF-i to treat persistent monoarthritis in RA patients.

\section{Materials and methods Eligibility criteria}

This systematic review was conducted in accordance with the recommendations of Preferred Reporting Items for Systematic Reviews and Meta-analysis (PRISMA) [5]. Studies fulfilling the following criteria were included: 1) randomized, controlled trials with an objective of evaluating efficacy of novel (defined as disease modifying anti-rheumatic drugs [DMARD] e.g. methotrexate and/ or biologics e.g. etanercept) IA agents against standard of care IA agents e.g. corticosteroids, 2) studies included patients with rheumatoid arthritis and/or persistent inflammatory arthritis, 3) studies enrolled human subjects.

\section{Search strategy and information sources}

A literature search was conducted on 10th August 2020 by a trained, experienced medical librarian utilizing medical subject heading $(\mathrm{MeSH})$ and text words related to the study question. The following keywords and their combinations were used in the search strategy to identify various DMARD IA therapies that may have been described in the literature: "intra-articular joint injection"; "intra-articular injection"; "rheumatoid arthritis"; "arthritis"; "antirheumatic agents"; "anti-inflammatory agents"; "immunosuppressive agents"; "abatacept"; "monoclonal antibodies"; "belimumab"; "certolizumab pegol"; "certolizumab"; "cyclophosphamide"; "cyclosporine"; "etanercept"; "leflunomide"; "methotrexate"; "sirolimus"; "adalimumab"; "enbrel"; and "infliximab". The following $\mathrm{MeSH}$ terms were used in conjunction with their keyword counterparts. Keywords and $\mathrm{MeSH}$ terms were combined using the Boolean operators "AND" and "OR". A sample search strategy is given as supplementary Table 1 .
Searched databases included Ovid MEDLINE, Ovid EMBASE, Scopus, and Web of Science. There was no publication date limit. Search was restricted to English language studies. Non randomized studies, studies with non-adult population studies and non-English studies were excluded. Conference abstracts were not excluded. Bibliography of identified studies was scanned to identify further studies for inclusion. Additional relevant studies identified from review articles on topics of intra-articular joint injections and rheumatoid arthritis therapy were also included. Per the 2020 PRISMA checklist, a sample strategy is provided in the supplementary material.

\section{Study selection and data collection}

Reference duplication assessment and data management were performed with EndNote library (version X9, Clarivate analytics). Two authors (FA and MM) independently sorted the identified abstracts for inclusion in the review. The full text article was reviewed for inclusion determination if an abstract was not available at this stage. The identified abstracts led to full-text review by each of the two authors for eligibility. Conflicts were resolved by consensus. Exclusions of full-text papers were recorded with their listed exclusion criteria. Information from the final included papers was reported by one reviewer (MM), and then reexamined by the second reviewer (FA) for accuracy. Data recorded included first author, publication year, study location, study design, study participant number, treatment arm regimens, outcome assessments, and adverse reactions to therapeutic interventions. Due to expected study heterogeneity, summary measures were not calculated

\section{Assessment of methodologic quality}

The risk of bias in included studies was further evaluated by the Cochrane Risk of Bias 2 (RoB2) for randomized trials [6]. The RoB2 assesses risk of bias in five domains, including the randomization process, intended interventions, missing outcome data, measurement of outcome, and selection of the reported result. Each domain is rated as: high risk of bias, low risk of bias, or unclear risk of bias. Two authors (MM and MP) independently assessed the studies and resolved conflicts through consensus. In absence of consensus, an additional author (FA) gave the final assessment.

\section{Results}

A total of 1013 citations were retrieved from the medical database searches. After removing duplicate references, 808 citations were reviewed based on inclusion and exclusion criteria. Full texts of 39 studies were reviewed, of which 29 were excluded:16 for the incorrect study type and 12 for an intervention other than IA DMARDs. Two additional studies were identified on bibliography review 
of the relevant literature. 12 studies were included in the final review. Study selection flowchart is shown in Fig. 1. Six studies investigated IA methotrexate while five studied IA etanercept. One study investigated different biologic agents: infliximab, etanercept, or adalimumab. Additional studies evaluating adalimumab did not meet our inclusion criteria.

\section{Intraarticular methotrexate}

Table 1 gives the details of the six included studies. Five studies evaluated knees only and the only study not doing so, studied elbows, wrists and ankles. The included studies had variable methotrexate dosing (ranging from $5 \mathrm{mg}$ to $80 \mathrm{mg}$ ), administration protocols, follow-up durations and outcome measures. Three of the six studies did not report on adverse effects.

The first randomized trial compared IA methotrexate plus IA hydrocortisone with IA hydrocortisone alone in 12 RA patients with persistent knee synovitis [7]. No incremental benefit from IA methotrexate, based on clinical assessment at 3 months, was detected. They did not report on adverse effects. Then in 1977, Bird and colleagues randomized 42 inflammatory arthritis patients, mostly RA but some with psoriatic arthritis, to IA triamcinolone or IA methotrexate for knee synovitis [8]. The methotrexate dosing was variable. With thermographic index as the primary outcome, methotrexate was inferior to triamcinolone, in both the RA and psoriatic arthritis patients. They did not report on adverse effects. Hall and colleagues performed a randomized double blind trial in 15 RA patients, comparing IA MTX (given as three doses) with IA saline for knee synovitis [9]. All patients had arthroscopic saline washout at the onset, before trial medicine administration. At 3 month arthroscopic assessment, no significant difference between the two groups was found. They also studied 5 patients with psoriatic arthritis and noticed some shortterm benefit from IA methotrexate in this group. They did not report on adverse effects. Both the aforementioned studies made the interesting observation of the injected MTX entering the contralateral non-injected knee within an hour $[8,9]$. A larger study looked at 82 RA patients with persistent knee symptoms [10]. They had three intervention arms: IA triamcinolone, IA triamcinolone plus IA methotrexate, and IA triamcinolone plus IA rifampin. At 3 months, the rifampin group had better control, based on a pain-scale outcome, but at 6 months, all groups were similar. Two (7.0\%) patients in the methotrexate group reported post-injection pain compared to 11 in the rifampin group. One (3.5\%) methotrexate group patient developed mouth ulcers at day 10 . The 2004 study by Hasso compared IA MTX plus triamcinolone $(20 \mathrm{mg}$ each) with IA triamcinolone $(20 \mathrm{mg})$ alone in 38 patients with inflammatory knee synovitis [11]. 23 patients had RA and the rest had other seronegative arthritides. No meaningful difference was noted between the two groups at 24 weeks of follow-up. No local adverse side effects occurred in either group.

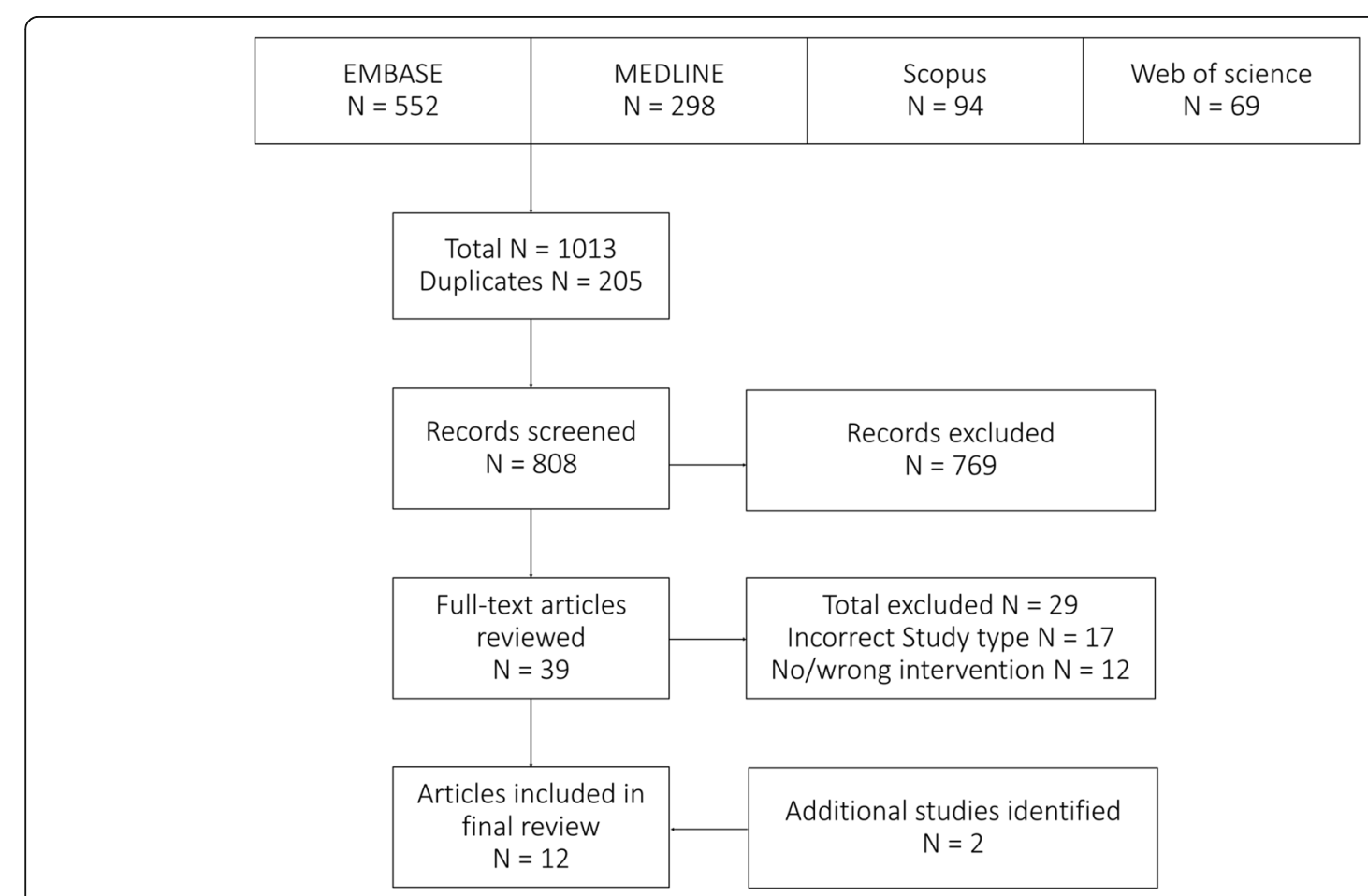

Fig. 1 Study selection flowchart for systematic review 
Table 1 Randomized Control Trials Evaluating Intraarticular Methotrexate for Persistent Monoarthritis in RA

\begin{tabular}{|c|c|c|c|c|c|c|c|c|c|}
\hline $\begin{array}{l}\text { Author, } \\
\text { Year, } \\
\text { Country }\end{array}$ & $\mathrm{N}$ of RA & Objective (s) & $\begin{array}{l}\text { Study } \\
\text { Design }\end{array}$ & $\begin{array}{l}\text { Time } \\
\text { in } \\
\text { Weeks }\end{array}$ & $\begin{array}{l}\text { Primary } \\
\text { Outcome }\end{array}$ & Joints & Results* & Conclusions & Side Effects \\
\hline $\begin{array}{l}\text { Marks } \\
\text { [7], 1976, } \\
\text { United } \\
\text { Kingdom }\end{array}$ & $\begin{array}{l}12 \\
\text { unclear } \\
\text { allocation } \\
\text { distribution }\end{array}$ & $\begin{array}{l}\text { Comparison of } \\
\text { IA MTX }+ \\
\text { hydrocortisone } \\
\text { vs } \\
\text { hydrocortisone } \\
\text { alone }\end{array}$ & $\begin{array}{l}\text { Randomized, } \\
\text { Single-blind }\end{array}$ & 36 & $\begin{array}{l}\text { Pain and } \\
\text { physician } \\
\text { assessment. } \\
\text { Not clearly } \\
\text { specified. }\end{array}$ & Knee & $\begin{array}{l}5 \text { patients in each } \\
\text { group felt } \\
\text { improvement } \\
\text { following injection, } \\
3 \text { patients had } \\
\text { objective } \\
\text { improvement on } \\
\text { knee examination } \\
\text { in each group }\end{array}$ & $\begin{array}{l}\text { MTX+ } \\
\text { hydrocortisone } \\
\text { was not superior } \\
\text { to hydrocortisone } \\
\text { alone }\end{array}$ & $\begin{array}{l}\text { No adverse } \\
\text { events reported, } \\
\text { though CBC and } \\
\text { LFT's had been } \\
\text { evaluated }\end{array}$ \\
\hline $\begin{array}{l}\text { Bird [8], } \\
1977, \\
\text { England }\end{array}$ & $\begin{array}{l}42 \text { total, } 23 \\
\text { with RA } \\
\text { MTX: } 9 \\
\text { Steroid: } 14\end{array}$ & $\begin{array}{l}\text { Comparison of } \\
\text { IA MTX with IA } \\
\text { triamcinolone } \\
\text { hexacetonide } \\
\text { by } \\
\text { thermography }\end{array}$ & Randomized & 3 & Thermography & Knee & $\begin{array}{l}\text { The thermographic } \\
\text { index improved in } \\
\text { the triamcinolone } \\
\text { group and was } \\
\text { sustained through } \\
3 \text { weeks }(0.02>p> \\
0.01 \text { at } 7 \text { and } 14 \\
\text { days) when } \\
\text { compared with } \\
\text { MTX. More } \\
\text { patients rated their } \\
\text { pain as improved } \\
\text { in the steroid } \\
\text { group }(p<0.0005)\end{array}$ & $\begin{array}{l}\text { Triamcinolone was } \\
\text { superior to MTX in } \\
\text { reducing } \\
\text { thermographic } \\
\text { indices of injected } \\
\text { knee joints }\end{array}$ & Not discussed \\
\hline $\begin{array}{l}\text { Hall [9], } \\
1978, \\
\text { England }\end{array}$ & $\begin{array}{l}20 \text { total, } 15 \\
\text { with RA } \\
\text { MTX: } 3 \\
\text { Saline: } 4 \\
\text { MTX \& } \\
\text { saline to } \\
\text { one knee } \\
\text { apiece: } 8\end{array}$ & $\begin{array}{l}\text { Comparison of } \\
\text { IA MTX vs } \\
\text { Saline }\end{array}$ & $\begin{array}{l}\text { Randomized, } \\
\text { Double-blind }\end{array}$ & 12 & $\begin{array}{l}\text { Clinical } \\
\text { assessment; } \\
\text { Arthroscopy } \\
\text { findings on } \\
\text { day } 0 \text { and } \\
\text { after } 12 \text { weeks }\end{array}$ & Knee & $\begin{array}{l}\text { Clinical measures } \\
\text { improved in both } \\
\text { groups, though } \\
\text { there were not } \\
\text { differences } \\
\text { between groups. } \\
\text { Less synovial } \\
\text { inflammation was } \\
\text { seen on 3-month } \\
\text { arthroscopy re- } \\
\text { gardless of treat- } \\
\text { ment group }\end{array}$ & $\begin{array}{l}\text { No benefit of MTX } \\
\text { over saline }\end{array}$ & Not assessed \\
\hline $\begin{array}{l}\text { Blyth } \\
\text { [10], } \\
1998 \\
\text { Scotland }\end{array}$ & $\begin{array}{l}82 \\
\text { Steroid: } 27 \\
\text { Steroid + } \\
\text { MTX: } 28 \\
\text { Steroid + } \\
\text { Rifampicin: } \\
27\end{array}$ & $\begin{array}{l}\text { Comparative } \\
\text { study of IA } \\
\text { triamcinolone, } \\
\text { triamcinolone } \\
\text { and rifampicin, } \\
\text { and } \\
\text { triamcinolone } \\
\text { and MTX }\end{array}$ & $\begin{array}{l}\text { Randomized, } \\
\text { Single-blind }\end{array}$ & 24 & $\begin{array}{l}\text { 5-point pain } \\
\text { scale }\end{array}$ & Knee & $\begin{array}{l}\text { Triamcinolone }+ \\
\text { rifampicin resulted } \\
\text { in statistically } \\
\text { significant pain } \\
\text { control at } 3 \\
\text { months ( } p=0.039 \text { ), } \\
\text { and the } \\
\text { percentage of pain } \\
\text { free patients was } \\
\text { higher ( } p<0.001 \text { ). } \\
\text { All groups } \\
\text { improved } \\
\text { compared to } \\
\text { baseline, but no } \\
\text { significant } \\
\text { differences noted } \\
\text { between } \\
\text { triamcinolone } \\
\text { +MTX to } \\
\text { triamcinolone } \\
\text { alone }\end{array}$ & $\begin{array}{l}\text { Addition of MTX } \\
\text { to triamcinolone } \\
\text { did not provide } \\
\text { any additional } \\
\text { relief }\end{array}$ & $\begin{array}{l}11 / 28 \text { patients } \\
\text { had post- } \\
\text { injection pain } \\
\text { flares with rifam- } \\
\text { picin. } 1 \text { patient } \\
\text { who received } \\
\text { MTX had mouth } \\
\text { ulcers } 10 \text { days } \\
\text { after injection }\end{array}$ \\
\hline $\begin{array}{l}\text { Hasso } \\
{[11],} \\
2004, \\
\text { United } \\
\text { Kingdom }\end{array}$ & $\begin{array}{l}38,29 \text { with } \\
\text { RA } \\
\text { MTX }+ \\
\text { steroid: } 20 \\
\text { Steroid: } 18\end{array}$ & $\begin{array}{l}\text { Comparison of } \\
\text { IA MTX + } \\
\text { triamcinolone } \\
\text { vs } \\
\text { triamcinolone } \\
\text { alone in knee } \\
\text { synovitis }\end{array}$ & $\begin{array}{l}\text { Randomized, } \\
\text { Double-blind }\end{array}$ & 24 & $\begin{array}{l}\text { Patient and } \\
\text { assessor global } \\
\text { assessments of } \\
\text { disease } \\
\text { activity, knee } \\
\text { pain VAS, } \\
\text { duration of } \\
\text { stiffness, joint }\end{array}$ & Knee & $\begin{array}{l}\text { Symptoms scores } \\
\text { improved } \\
\text { significantly in } \\
\text { both groups with } \\
\text { worsening } \\
\text { between week 12- } \\
24 \text {, but no } \\
\text { difference }\end{array}$ & $\begin{array}{l}\text { The addition of } \\
\text { MTX to steroid } \\
\text { injection did not } \\
\text { improve symptom } \\
\text { scores or clinical } \\
\text { response } \\
\text { compared with } \\
\text { triamcinolone }\end{array}$ & $\begin{array}{l}11 \text { patients had } \\
\text { mild elevation } \\
\text { of liver } \\
\text { transaminases, } \\
\text { did not clarify } \\
\text { treatment group }\end{array}$ \\
\hline
\end{tabular}


Table 1 Randomized Control Trials Evaluating Intraarticular Methotrexate for Persistent Monoarthritis in RA (Continued)

\begin{tabular}{|c|c|c|c|c|c|c|c|c|c|}
\hline $\begin{array}{l}\text { Author, } \\
\text { Year, } \\
\text { Country }\end{array}$ & $\mathrm{N}$ of $\mathrm{RA}$ & Objective (s) & $\begin{array}{l}\text { Study } \\
\text { Design }\end{array}$ & $\begin{array}{l}\text { Time } \\
\text { in } \\
\text { Weeks }\end{array}$ & $\begin{array}{l}\text { Primary } \\
\text { Outcome }\end{array}$ & Joints & Results* & Conclusions & Side Effects \\
\hline & & & & & circumference & & $\begin{array}{l}\text { between treatment } \\
\text { groups. } 9 \text { patients } \\
\text { required repeat } \\
\text { corticosteroid } \\
\text { injections ( } 5 \text { in the } \\
\text { triamcinolone } \\
\text { group and } 4 \text { in the } \\
\text { MTX group) }\end{array}$ & $\begin{array}{l}\text { alone in chronic } \\
\text { knee synovitis }\end{array}$ & \\
\hline $\begin{array}{l}\text { Mortada } \\
{[12]} \\
2018 \\
\text { Egypt }\end{array}$ & $\begin{array}{l}100 \\
\text { MTX: } 56 \\
\text { Steroid: } 44\end{array}$ & $\begin{array}{l}\text { Comparison of } \\
\text { IA MTX vs } \\
\text { triamcinolone } \\
\text { acetonide }\end{array}$ & $\begin{array}{l}\text { Randomized, } \\
\text { Single-blind }\end{array}$ & 20 & $\begin{array}{l}\text { VAS, US } \\
\text { findings }\end{array}$ & $\begin{array}{l}\text { Ankle, } \\
\text { wrist, } \\
\text { and } \\
\text { elbow }\end{array}$ & $\begin{array}{l}\text { Clinical parameters } \\
\text { and ultrasound } \\
\text { findings improved } \\
\text { in both groups by } \\
\text { week } 8 \text {. The } \\
\text { clinical } \\
\text { improvement } \\
\text { continued in the } \\
\text { MTX group to } \\
\text { week 20, but } \\
\text { plateaued in the } \\
\text { steroid group ( } p= \\
\text { 0.04) }\end{array}$ & $\begin{array}{l}\text { Repeated IA MTX } \\
\text { injections resulted } \\
\text { in a decrease of } \\
\text { synovitis in } \\
\text { medium-sized } \\
\text { joints when com- } \\
\text { pared with a sin- } \\
\text { gle triamcinolone } \\
\text { injection }\end{array}$ & $\begin{array}{l}2 \text { participants in } \\
\text { MTX group had } \\
\text { oral ulcers, } 1 \\
\text { had post- } \\
\text { injection nausea. } \\
3 \text { in the steroid } \\
\text { group had joint } \\
\text { flares }\end{array}$ \\
\hline
\end{tabular}

CBC complete blood count; LFT liver function tests; MTX methotrexate; $N$ number; $R A$ rheumatoid arthritis; US ultrasound; VAS visual analog scale

*: When not given, $p$-value was not reported in the study or was statistically not significant

The most recent trial investigating IA methotrexate was from 2018 [12]. This study enrolled 100 RA patients and was unique as it included elbows, wrists and ankles but no knees. One group received IA triamcinolone $40 \mathrm{mg}$ once in the affected joint, while the other group received weekly IA methotrexate at $10 \mathrm{mg}$ per injection for 8 weeks. All injections were with ultrasound (US) guidance. At 20 weeks, they found IA MTX was superior to IA triamcinolone in terms of pain scores and US parameters (both grayscale and Doppler). In terms of adverse effects, two (3.5\%) patients in the methotrexate group developed oral ulcers while one (1.8\%) developed post-injection nausea. Three $(6.9 \%)$ patients in the triamcinolone group reported post-injection arthritis flare.

\section{Intraarticular etanercept}

Table 2 encompasses the findings of the intraarticular TNFi therapies. Bliddal et al. investigated single injections of IA etanercept $25 \mathrm{mg}$ vs. IA methylprednisolone $40 \mathrm{mg}$ under US guidance in $38 \mathrm{RA}$ patients [13]. RA flare in a joint (elbow, wrist or knee) was treated, with wrists being the most common. At 4 weeks follow-up, there was no difference in pain outcome between the two groups. One patient (5.6\%) in the TNF-i group developed a lower extremity rash while one patient $(5.0 \%)$ in the steroid group developed atrial fibrillation. A 2008 study compared the effectiveness of single IA etanercept $25 \mathrm{mg}$ vs. IA methylprednisolone $40 \mathrm{mg}$ under US guidance in the wrist joints of $25 \mathrm{RA}$ patients [14]. In addition to clinical outcomes, they also assessed response by US and magnetic resonance imaging (MRI). The outcomes in both groups were similar. Notably, clinical improvement was noted in both groups but, surprisingly, imaging improvement was absent; in fact, deterioration was noted. They did not report on adverse effects. Roux from France compared IA etanercept 25 $\mathrm{mg}$ vs. IA betamethasone $4 \mathrm{mg}$, given under radiographic guidance, in elbow, wrist (most common), and knee or ankle monoarthritis in 34 randomized RA patients [15]. Clinical outcomes were similar, with both groups showing significant improvement, at 4 and 24 weeks. One (5.9\%) phlebitis occurrence was noted in the etanercept group. Aalbers et al. investigated 11 RA patients (9 knee joints), as part of a larger group of 30 patients (the rest with psoriatic arthritis), for efficacy of a single IA etanercept $25 \mathrm{mg}$ vs. IA normal saline [16]. Etanercept led to a statistically significant improvement in composite outcomes at 2 weeks, with the pain response sustained till 6 weeks. Overall adverse events were not statistically significant between the two groups. The most recent study investigating etanercept was from 2020 [18]. 50 RA patients with active monoarthritis were randomized to either a single IA etanercept ( $25 \mathrm{mg}$ for wrist and ankle joints and $50 \mathrm{mg}$ for knee joints) vs. IA methylprednisolone $40 \mathrm{mg}$ in all joints, under US guidance. At week 1, etanercept was better; at week 4, both were equal; and at week 12, methylprednisolone was better based on clinical assessment outcomes. US results were mixed. No serious adverse effects occurred. 


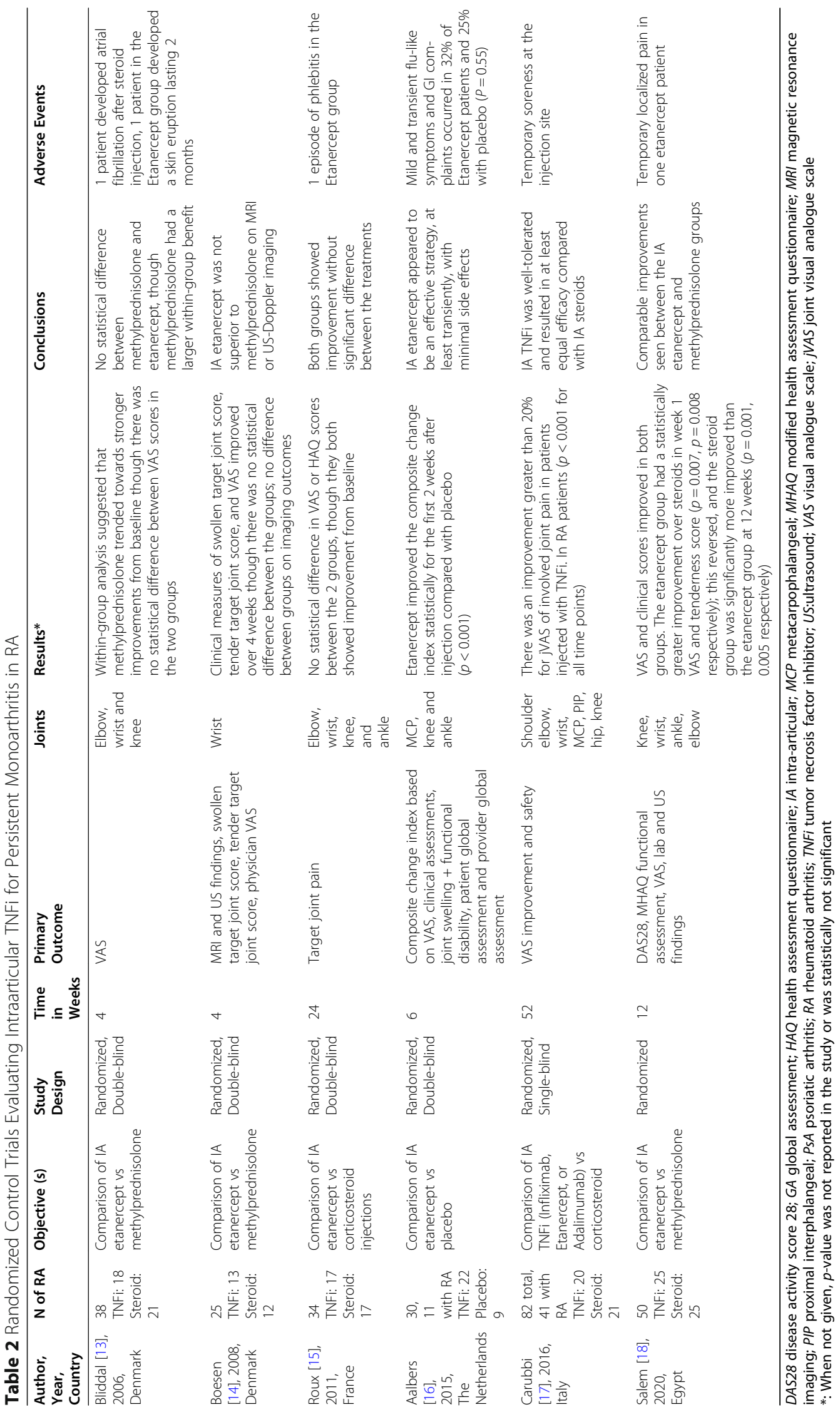




\section{Other intraarticular TNF-i}

This Italian study had $41 \mathrm{RA}$ patients [17]. They compared IA TNF-i (adalimumab 40 or etanercept 50 or infliximab 100) $\mathrm{mg}$ vs. IA triamcinolone $40 \mathrm{mg}$, each injected monthly under US guidance for a total of 3 doses. Wrists, metacarpophalangeal joints and knees were the most commonly involved joints. Interestingly, patients were also on systemic TNF-i therapy. The agent used for systemic therapy was utilized for intra-articular therapy if they were randomized to the TNFi treatment arm. Primary outcome was a visual pain scale, with imaging based secondary outcomes. Pain outcomes were significantly better in the TNF-i group up to 24 weeks of follow-up. Gray-scale and Doppler US as well as MRI improvements were significantly more pronounced in the TNF-i group. The response was better in the large joints. Clinical remission was achieved earlier in the TNF-i group (4 weeks) vs. the triamcinolone $(8$ weeks) group. The TNF-i group had no flares compared to several in the triamcinolone group at 52 weeks of follow-up. They noted that the TNF-i effect was independent of the type of TNF-i. No serious adverse events were reported.

\section{Risk of Bias assessment}

Out of the 6 included trials that evaluated IA methotrexate, 4 of the studies were deemed at high risk of bias, 1 with some concern of bias, and 1 with low risk of bias (Table 3). In trials evaluating IA TNFi therapy, 1 study was deemed at high risk of bias, 1 with concern for bias, and 4 studies were considered at lower risk of bias (Table 4).

\section{Discussion}

There is an unmet need of IA agents to control active inflammatory monoarthritis in patients with underlying inflammatory joint diseases, primarily RA, when IA corticosteroids fail to work, lose efficacy or cause adverse effects and systemic therapy is not the preferred option. MTX and etanercept have been most studied in this respect.

MTX has been studied as an IA agent either in combination with corticosteroids or as a substitute for corticosteroids in refractory monoarthritis. A 2004 Welsh study anecdotally mentioned that IA MTX and IA corticosteroid combination was being commonly used [11]. In our analysis, MTX was not found to be a useful treatment for mono-articular synovitis of the knee. Studies comparing IA MTX to IA saline and addition of IA MTX to other IA corticosteroids showed no benefit. What about using IA MTX in place of IA corticosteroids, if the latter are ineffective or contraindicated? The only study with a head-to-head equivalent comparison of IA MTX with IA corticosteroids found no benefit with MTX thus casting doubt on using IA MTX as an corticosteroid alternative [8]. The only study that favored IA MTX comparing it to IA corticosteroids, and evaluating non-knee joints, was the 2018 study comparing one IA triamcinolone injection to a total of eight IA MTX injections given weekly [12]. Notably, this was also the only study, in our review, that studied joints other than the knees (all other studies investigated the knee joints). However, any meaningful conclusion is difficult to ascertain because of this major difference in the administration frequency. Additionally, weekly IA MTX may not be clinically feasible. What we can extrapolate is that weekly IA injections of MTX do not have any substantial short-term adverse effects. In summary, there is no evidence in favor of using IA MTX for treatment of persistent knee synovitis. There may be some very weak evidence to support its use in non-knee monoarthritis.

IA corticosteroids has been an integral part of RA management. However, this may not remain the case in the future, necessitating alternate choices. In osteoarthritis, IA corticosteroid use is starting to fall out of favor due to lack of benefit and concerns for adverse effects. Some osteoarthritis studies have raised concerns about cartilage damage from IA corticosteroid exposure in addition to the lack of response [19]. The clinical relevance of such cartilage degradation, however, is unclear at the individual patient level [20]. While many new agents are under investigation as IA agents for OA, such momentum is lacking in RA.

One potential reason for this lack of benefit, especially from single IA MTX injections, is due to the elimination half-life of IA MTX which is just $2.9 \mathrm{~h}$ [21]. This time is insufficient for any cytotoxic effect to cause a chemical synovectomy. Therefore, there may be some rationale behind repeated IA injections of MTX and indeed the 2018 study in our analysis showed a response [12]. These pharmacodynamics have generated an interest in developing conjugated compounds to provide longer retention of IA MTX [22]. For reference, the half-life of IA triamcinolone acetonide is between 3.2 and 6.4 days [23]. Others have postulated that methotrexate does not have significant intracellular uptake with IA administration, and this could decrease the adenosine release hypothesized to be a major mechanism of action in rheumatoid arthritis $[24,25]$.

TNF is found in inflamed joints and thus a therapeutic response from an IA TNF-i injection is expected [26]. IA TNF-i can bind the local TNF to ameliorate inflammation and pain. It is possible that lack of TNF-i uptake in a joint may be the reason for persistent monoarthritis in an otherwise well-controlled RA patient on TNF-I therapy. This may be particularly true for the knee joint with its large synovial surface area and higher inflammatory 
Table 3 Revised Cochrane risk-of-bias tool for randomized trial for intra-articular methotrexate trials

\begin{tabular}{|c|c|c|c|c|c|c|}
\hline $\begin{array}{c}\text { Author \& } \\
\text { Year of } \\
\text { Publication }\end{array}$ & $\begin{array}{c}\text { Randomization } \\
\text { Process }\end{array}$ & $\begin{array}{l}\text { Intended } \\
\text { Interventions }\end{array}$ & $\begin{array}{c}\text { Missing } \\
\text { Outcome } \\
\text { Data }\end{array}$ & $\begin{array}{c}\text { Measurement } \\
\text { of Outcome }\end{array}$ & $\begin{array}{c}\text { Selection of } \\
\text { the } \\
\text { Reported } \\
\text { Result }\end{array}$ & $\begin{array}{l}\text { Overall } \\
\text { Risk of } \\
\text { Bias }\end{array}$ \\
\hline Bird 1977 & & & $\square$ & & & \\
\hline Blyth 1998 & ? & & & & & 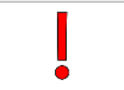 \\
\hline Hall 1978 & ? & 几5 & 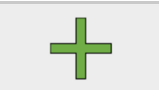 & ? & & Pr \\
\hline Hasso 2004 & ص & L & 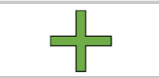 & 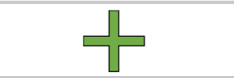 & 万 & بإ \\
\hline Marks 1976 & 5 & 5 & ? & & ? & \\
\hline Mortada 2018 & & ? & 5 & P & P & \\
\hline
\end{tabular}

Key: $\tau^{2}=$ Low risk of bias $\vec{g}=$ Some concern of bias $!=$ High risk of bias

milieu. IA etanercept studies included in our review were more helpful, compared to the IA MTX studies, as they all compared etanercept with IA corticosteroids or saline. No head-to-head IA corticosteroid study showed inferiority of IA etanercept [13-15]. Thus, IA etanercept could potentially be used in lieu of an IA corticosteroid, if needed. More importantly, and unlike IA MTX, IA etanercept was superior when compared to normal saline at 2 weeks [16]. This 2 week response duration is consistent with the half-life of etanercept, which is $68 \mathrm{~h}$ based on subcutaneous administration as IA half-life is unknown [27]. Rapid joint clearance, mediated by an efficient lymphatic drainage system, remains a challenge for IA therapies. Another study also showed the superiority of etanercept compared to methlyprednisone at 1 week, equality at 4 weeks and superiority of methlyprednisone at 12 weeks [18]. The important question of the utility of serial IA etanercept injections, like every 3 months similar to corticosteroids, has not been investigated. The study by Roux et al. showed sustained similarity in response between IA etanercept and IA betamethasone till 24 weeks, which is encouraging [15]. The study by Carubbi investigated three IA TNF-i (adalimumab, etanercept and infliximab) compared to IA corticosteroids and found IA TNF-i to generate significantly superior clinical and imaging outcomes [17].

Table 4 Revised Cochrane risk-of-bias tool for randomized trial for intra-articular TNFi trials

\begin{tabular}{|c|c|c|c|c|c|c|}
\hline $\begin{array}{c}\text { Author \& } \\
\text { Year of } \\
\text { Publication }\end{array}$ & $\begin{array}{c}\text { Randomization } \\
\text { Process }\end{array}$ & $\begin{array}{c}\text { Intended } \\
\text { Interventions } \\
\end{array}$ & $\begin{array}{c}\text { Missing } \\
\text { Outcome } \\
\text { Data }\end{array}$ & $\begin{array}{c}\text { Measurement } \\
\text { of Outcome }\end{array}$ & $\begin{array}{c}\text { Selection of } \\
\text { the } \\
\text { Reported } \\
\text { Result }\end{array}$ & $\begin{array}{c}\text { Overall } \\
\text { Risk of } \\
\text { Bias } \\
\end{array}$ \\
\hline Aalbers 2015 & ? & كل & & ك & ? & ? \\
\hline Bliddal 2006 & كّ & كّل & & ש & 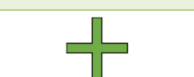 & \\
\hline Boesen 2008 & & & & & & \\
\hline Carubbi 2016 & كـ & ك & 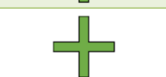 & 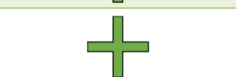 & 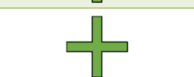 & \\
\hline Roux 2011 & ك马 & كط & ᄃ & $=$ & $\sqrt{n}$ & \\
\hline Salem 2020 & & ? & ك & & ? & \\
\hline
\end{tabular}

Key: $=$ = Low risk of bias 
Reassuringly, they also did not report any concerning adverse effects especially considering patients were also on parenteral TNF-i (similar to the IA agent). None of the included studies in our review investigated combined IA corticosteroid and TNF-i. However, a case series showed sustained 12 months remission when the active joint with synovitis was injected with such a combination [28]. Adalimumab (40 mg) was the main TNF-i (four out of five patients) used in this series. It is notable, that the benefit was only seen in TNF-i naïve patients. An uncontrolled study has shown infliximab as an effective IA therapy, even in patients already taking a TNF-i [29]. Ultrasound findings did show an improvement in this study. On the contrary, some infliximab series have not shown any benefit [30]. There is some basis to suggest efficacy from a second IA TNF-i injection as the first one may help reduce vascularity thus limiting systemic absorption and promoting a longer local effect from the subsequent injection $[1,31]$.

Overall, the IA therapy with MTX and TNF-i was well-tolerated with no notable adverse effects in the included studies. US usage ensured proper drug placement and allayed concerns of IA reactions from TNF-i placement [32]. We do note a case of development of miliary tuberculosis after an IA TNF-i injection [33]. Therefore, infection screening process prior to IA TNF therapy should be similar to that of systemic therapy. Anti-drug antibody formation after a single IA TNF-i has been reported [34].

Our study appears to be the first systematic review investigating the utility of non-corticosteroid immunosuppressive IA therapies for persistent monoarthritis in inflammatory arthritis patients. Considering the study question, publication bias risk is possible but less likely because even a negative result should not preclude publication. Limitations of this systematic review include the exclusion of non-English language studies which may create bias, variability in treatment doses, and heterogeneity of study protocols. Since these studies assessed intra-articular therapies, a strong component of placebo therapeutic response is possible and cannot be discounted [35]. Most of the studies investigating TNF-i had low risk of bias while MTX studies generally had higher bias risk. No cost-effectiveness analyses were reported.

\section{Conclusion}

In conclusion, MTX likely has minimal utility, if any, as an IA agent for treatment of monoarthritis in patients with inflammatory arthritis. TNF-i in general, and specifically etanercept, have data supporting their use as IA agents in select patients with inflammatory arthritis when systemic treatment is not an option and IA corticosteroids cannot be used. More research is needed to investigate the optimal dose and frequency of IA TNF-i as well as to investigate the long-term results of IA TNF-i therapy. Cost-effectiveness data is also needed. Development of novel IA agents will greatly facilitate treatment of inflammatory monoarthritis.

\section{Supplementary Information}

The online version contains supplementary material available at https://doi. org/10.1186/s12891-021-04651-5.

Additional file 1. Supplementary Table 1: Sample search strategy.)

Authors' contributions

FW and MM wrote the majority of the article. MM and MP performed the Cochrane assessment, with FW serving as a 3rd opinion if disagreements occurred. LM performed the systematic review to identify articles for inclusion. The author(s) read and approved the final manuscript.

\section{Funding}

No specific funding was received from any bodies in the public, commercial or not-for-profit sectors to carry out the work described in this article.

Availability of data and materials

The data utilized for this article can be found individually through the articles assessed, or the dataset can be requested from the authors.

\section{Declarations}

Ethics approval and consent to participate

This systematic literature review was conducted using ethical standards. Given the type of manuscript, no specific ethics approval or consent was required.

\section{Consent for publication}

All authors understand BMC Musculoskeletal Disorders is an open access journal and agree to publication with the journal if accepted.

\section{Competing interests}

There are no competing interests to report from any of the authors.

\section{Author details}

${ }^{1}$ Division of Rheumatology, Department of Internal Medicine Mayo Clinic, 4500 San Pablo Road, Jacksonville, FL 32224, USA. ²Division of Rheumatology, Department of Internal Medicine Mayo Clinic, Scottsdale, AZ, USA. ${ }^{3}$ Mayo Clinic Libraries Arizona, Mayo Clinic, Scottsdale, AZ, USA.

Received: 15 May 2021 Accepted: 5 August 2021

Published online: 15 September 2021

\section{References}

1. Fisher BA, Keat A. Should we be using intraarticular tumor necrosis factor blockade in inflammatory monoarthritis? J Rheumatol. 2006;33(10):1934-5.

2. Weitoft $T$, Uddenfeldt $P$. Importance of synovial fluid aspiration when injecting intra-articular corticosteroids. Ann Rheum Dis. 2000;59(3):233-5. https://doi.org/10.1136/ard.59.3.233.

3. Kim SJ, Jung KA. Arthroscopic synovectomy in rheumatoid arthritis of wrist. Clin Med Res. 2007;5(4):244-50. https://doi.org/10.3121/cmr.2007.768.

4. Amini A, Yahyanezhad S, Velez E, Gholamrezanezhad A, Fotoohi M, Jafari E, et al. Prospective evaluation of phosphorus-32 radiation synovectomy in patients with severe and chronic rheumatoid arthritis unresponsive to conventional medical treatment. Nucl Med Commun. 2020;41(1):65-72. https://doi.org/10.1097/MNM.0000000000001116.

5. Liberati A, Altman DG, Tetzlaff J, Mulrow C, Gotzsche PC, loannidis JP, et al. The PRISMA statement for reporting systematic reviews and meta-analyses of studies that evaluate healthcare interventions: explanation and elaboration. BMJ. 2009;339(jul21 1):b2700. https://doi.org/10.1136/bmj.b2700. 
6. Sterne JAC, Savovic J, Page MJ, Elbers RG, Blencowe NS, Boutron I, et al. RoB 2: a revised tool for assessing risk of bias in randomised trials. BMJ. 2019;366: 14898.

7. Marks JS, Stewart IM, Hunter JA. Intra-articular methotrexate in rheumatoid arthritis. Lancet. 1976;2(7990):857-8. https://doi.org/10.1016/s0140-673 6(76)91250-2.

8. Bird HA, Ring EF, Daniel R, Bacon PA. Comparison of intra-articular methotrexate with intra-articular triamcinolone hexacetonide by thermography. Curr Med Res Opin. 1977;5(2):141-6. https://doi.org/10.1185/ 03007997709110154.

9. Hall GH, Jones BJ, Head AC, Jones VE. Intra-articular methotrexate. Clinical and laboratory study in rheumatoid and psoriatic arthritis. Ann Rheum Dis. 1978;37(4):351-6. https://doi.org/10.1136/ard.37.4.351.

10. Blyth T, Stirling A, Coote J, Land D, Hunter JA. Injection of the rheumatoid knee: does intra-articular methotrexate or rifampicin add to the benefits of triamcinolone hexacetonide? Br J Rheumatol. 1998;37(7):770-2. https://doi. org/10.1093/rheumatology/37.7.770.

11. Hasso N, Maddison PJ, Breslin A. Intra-articular methotrexate in knee synovitis. Rheumatology (Oxford). 2004;43(6):779-82. https://doi.org/10.1093/ rheumatology/keh181.

12. Mortada MA, Abdelwhab SM, Elgawish MH. Intra-articular methotrexate versus corticosteroid injections in medium-sized joints of rheumatoid arthritis patients-an intervention study. Clin Rheumatol. 2018;37(2):331-7. https://doi.org/10.1007/s10067-017-3843-y.

13. Bliddal H, Terslev L, Qvistgaard E, Konig M, Holm CC, Rogind H, et al. A randomized, controlled study of a single intra-articular injection of etanercept or glucocorticosteroids in patients with rheumatoid arthritis. Scand J Rheumatol. 2006;35(5):341-5. https://doi.org/10.1080/0300974 0600844530 .

14. Boesen $M$, Boesen $L$, Jensen KE, Cimmino MA, Torp-Pedersen S, Terslev $L$, et al. Clinical outcome and imaging changes after intraarticular (IA) application of etanercept or methylprednisolone in rheumatoid arthritis: magnetic resonance imaging and ultrasound-Doppler show no effect of IA injections in the wrist after 4 weeks. J Rheumatol. 2008;35(4):584-91.

15. Roux $\mathrm{CH}$, Breuil V, Valerio L, Amoretti N, Broca O, Albert C, et al. Etanercept compared to intraarticular corticosteroid injection in rheumatoid arthritis: double-blind, randomized pilot study. J Rheumatol. 2011;38(6):1009-11. https://doi.org/10.3899/jrheum.100828.

16. Aalbers C, Gerlag D, Vos K, Vervoordeldonk M, Landewe R, Tak PP. Intraarticular etanercept treatment in inflammatory arthritis: a randomized double-blind placebo-controlled proof of mechanism clinical trial validating TNF as a potential therapeutic target for local treatment. Joint Bone Spine. 2015;82(5):338-44. https://doi.org/10.1016/j.jbspin.2015.03.002.

17. Carubbi F, Zugaro L, Cipriani P, Conchiglia A, Gregori L, Danniballe C, et al. Safety and efficacy of intra-articular anti-tumor necrosis factor alpha agents compared to corticosteroids in a treat-to-target strategy in patients with inflammatory arthritis and monoarthritis flare. Int J Immunopathol Pharmacol. 2016:29(2):252-66. https://doi.org/10.1177/0394632015593220.

18. Salem RM, El-Deeb AE, Elsergany M, Elsaadany H, El-Khouly R. Intra-articular injection of etanercept versus glucocorticoids in rheumatoid arthritis patients. Clin Rheumatol. 2020;40(2), 557-564. https://doi.org/10.1007/s1 0067-020-05235-9.

19. McAlindon TE, LaValley MP, Harvey WF, Price LL, Driban JB, Zhang M, et al. Effect of intra-articular triamcinolone vs saline on knee cartilage volume and pain in patients with knee osteoarthritis: a randomized clinical trial. JAMA. 2017;317(19):1967-75. https://doi.org/10.1001/jama.2017.5283.

20. Bacon K, LaValley MP, Jafarzadeh SR, Felson D. Does cartilage loss cause pain in osteoarthritis and if so, how much? Ann Rheum Dis. 2020;79(8): 1105-10. https://doi.org/10.1136/annrheumdis-2020-217363.

21. Wigginton SM, Chu BC, Weisman MH, Howell SB. Methotrexate pharmacokinetics after intraarticular injection in patients with rheumatoid arthritis. Arthritis Rheum. 1980;23(1):119-22. https://doi.org/10.1002/art.1 780230121.

22. Boechat AL, de Oliveira CP, Tarrago AM, da Costa AG, Malheiro A, Guterres SS, et al. Methotrexate-loaded lipid-core nanocapsules are highly effective in the control of inflammation in synovial cells and a chronic arthritis model. Int J Nanomedicine. 2015;10:6603-14. https:// doi.org/10.2147/IJN.S85369.

23. Derendorf H, Mollmann H, Gruner A, Haack D, Gyselby G. Pharmacokinetics and pharmacodynamics of glucocorticoid suspensions after intra-articular administration. Clin Pharmacol Ther. 1986;39(3):313-7. https://doi.org/10.103 8/clpt.1986.45

24. Tada M, Inui K, Okano T, Mamoto K, Koike T, Nakamura H. Safety of intraarticular methotrexate injection with and without electroporation for inflammatory small joints in patients with rheumatoid arthritis. Clin Med Insights Arthritis Musculoskelet Disord. 2019;12:117954411988630. https:// doi.org/10.1177/1179544119886303

25. Maksimovic V, Pavlovic-Popovic Z, Vukmirovic S, Cvejic J, Mooranian A, AlSalami H, et al. Molecular mechanism of action and pharmacokinetic properties of methotrexate. Mol Biol Rep. 2020;47(6):4699-708. https://doi. org/10.1007/s11033-020-05481-9.

26. Deleuran BW, Chu CQ, Field M, Brennan FM, Mitchell T, Feldmann M, et al. Localization of tumor necrosis factor receptors in the synovial tissue and cartilage-pannus junction in patients with rheumatoid arthritis. Implications for local actions of tumor necrosis factor alpha. Arthritis Rheum. 1992:35(10): 1170-8. https://doi.org/10.1002/art.1780351009.

27. Korth-Bradley JM, Rubin AS, Hanna RK, Simcoe DK, Lebsack ME. The pharmacokinetics of etanercept in healthy volunteers. Ann Pharmacother. 2000;34(2):161-4. https://doi.org/10.1345/aph.19126.

28. Haroon M, O'Gradaigh D. Efficacy and safety of combining intra-articular methylprednisolone and anti-TNF agent to achieve prolonged remission in patients with recurrent inflammatory monoarthritis. Joint Bone Spine. 2010; 77(3):232-4. https://doi.org/10.1016/j.jbspin.2010.02.008

29. Conti F, Ceccarelli F, Priori R, lagnocco A, Signore A, Valesini G. Intra-articular infliximab in patients with rheumatoid arthritis and psoriatic arthritis with monoarthritis resistant to local glucocorticoids. Clinical efficacy extended to patients on systemic anti-tumour necrosis factor alpha. Ann Rheum Dis. 2008;67(12):1787-90. https://doi.org/10.1136/ard.2008.091900.

30. Bokarewa M, Tarkowski A. Local infusion of infliximab for the treatment of acute joint inflammation. Ann Rheum Dis. 2003;62(8):783-4. https://doi. org/10.1136/ard.62.8.783

31. Taylor PC. Serum vascular markers and vascular imaging in assessment of rheumatoid arthritis disease activity and response to therapy. Rheumatology (Oxford). 2005;44(6):721-8. https://doi.org/10.1093/rheumatology/keh524.

32. Bliddal H, Terslev L, Qvistgaard E, Recke P, Holm CC, Danneskiold-Samsoe B, et al. Safety of intra-articular injection of etanercept in small-joint arthritis: an uncontrolled, pilot-study with independent imaging assessment. Joint Bone Spine. 2006;73(6):714-7. https://doi.org/10.1016/j.jbspin.2006.05.004.

33. Li SG. Clinical image: development of miliary tuberculosis following one intraarticular injection of etanercept. Arthritis Rheum. 2011;63(5):1364. https://doi.org/10.1002/art.30289.

34. Zufferey P, Perreau M, So A. High level of anti-drug antibodies after intraarticular injection of anti-TNF. Rheumatology (Oxford). 2015;54(12):2291-2. https://doi.org/10.1093/rheumatology/kev325.

35. Previtali D, Merli G, Di Laura FG, Candrian C, Zaffagnini S, Filardo G. The long-lasting effects of "placebo injections" in knee osteoarthritis: a Metaanalysis. Cartilage. 2020;18:1947603520906597. https://doi.org/10.1177/194 7603520906597 Epub ahead of print

\section{Publisher's Note}

Springer Nature remains neutral with regard to jurisdictional claims in published maps and institutional affiliations.

Ready to submit your research? Choose BMC and benefit from:

- fast, convenient online submission

- thorough peer review by experienced researchers in your field

- rapid publication on acceptance

- support for research data, including large and complex data types

- gold Open Access which fosters wider collaboration and increased citations

- maximum visibility for your research: over $100 \mathrm{M}$ website views per year

At BMC, research is always in progress.

Learn more biomedcentral.com/submissions 